\title{
Problems of Improvising Physics Instructional Materials as Perceived by Serving Teachers in Cross River State, Nigeria
}

\author{
Ndem Nsungo Udo \\ Physics Department, College of Education, Akamkpa Cross River State, Nigeria
}

\begin{abstract}
This study is a descriptive survey study carried out in Cross River State, Nigeria. Cross River State is one of the states in the south-south geopolitical zone of Nigeria. The sample for the study consisted of one hundred and sixty (160) physics teachers randomly drawn from the two hundred and forty three (243) secondary schools in the state. The instrument for data collection was the Physics Teachers Perceived Problems of Improvisation Questionnaire (PTPPIQ). The instrument was trial tested using thirty physics teachers in schools not used for the study. The results of the trial-test was analysed and a reliability index of 0.81 obtained using Cronbach Alpha. The instrument was then administered on the one hundred and sixty respondents and the results showed that factors such as inability to identify local materials needed for improvisation, lack of tools, excess workload on the teachers and voluminous nature of the syllabus among others, were identified as factors perceived by physics teachers as militating against improvisation. The study also revealed that these problems were not gender bias. The paper recommended among others, the motivation of physics teachers and that improvisation should be included in the pre-service physics teachers training programmes.
\end{abstract}

DOI: $10.7176 / \mathrm{JEP} / 10-5-10$

\section{Introduction}

Science has shaped the world today in such a way that nations all over the world (Nigeria inclusive) are striving towards and investing huge resources in order to develop scientifically and technologically. The world today is turning scientific and today effective functioning in all life endeavors depend greatly on the discovery made through science. Scientific investigations help man to know about the shape of the word in which man live. This is why Ogunleye (2008) saw science as a dynamic activity concerned with understanding the workings of our world.

Physics is one of the basic sciences that concerns itself with the study of properties of matter and the energy associated with such matter. Physics is needed in our day to today existence especially in today's technologydriven society. Thus the Federal Ministry of Education, Nigeria, (FME, 2009) recognized physics as a crucial subject for effective living in this modern age of science and technology. It is very central in all science and technology-based courses because a credit pass in physics is required for entry into these programmes. This implies that every student should be given the opportunity to acquire some basic physics concepts, theories, principles and skills for effective living in today's society. This is one of the objectives of teaching physics at the senior secondary school level. According to the National Policy on Education (NPE, 2013) objective of physics education includes to provide basic literacy in physics for functional living in the society; acquire essential scientific skills and attitudes as a preparation for technological application of physics, stimulation and enhancement of creativity, among others. Physics is an activity-oriented subject and thus requires instructional materials during the teaching/learning process. This shows that the mastery of physics concepts cannot be fully achieved without the use of instructional materials. According to Eze and Agbomma (2008), no matter how a teacher may be trained academically and professionally, he/she may not be able to transmit his competences into reality without the use of instructional materials.

Instructional materials are equipment and materials used for teaching by the teacher to stimulate selfactivity on students (Odo, 2015). Eniayeji (2005) defined instructional materials as materials which provide concrete experiences which a learner needs in order to develop intellectually. Instructional materials play a vital role in the teaching/learning process as far as physics is concerned. They help the mind of the learner on what is taught and also aids retention in the memory. Instructional materials boost teaching and learning, stimulate creative thinking and make leaning concrete (Ige, 2004). The successful implementation of the physics curriculum learns heavily on the provision of instructional materials. But researches such as that of Nwosu (2002), Foloruuso (2009), Obiona (2006) Onasaniyu and Omosewo (2011) and Odo (2015) have shown that physics instructional materials are lacking in our secondary schools. This calls for improvisation on the part of the teachers.

Improvisation is the process of using alternative materials for enhancing the teaching/learning process where there is absence of the standard instructional materials. According to Odo (2015), improvisation of instructional materials is an attempt to make use of local resources in the teaching/learning process when the ready-made (standard) materials are not available or are not within the reach of the users. Oyediran (2010) defined improvisation as the art of using materials or equipment obtained from local environment by the teacher 
or students and with or without the assistance of some local personnel like carpenters or blacksmiths. The merits of improvisation include:

- It makes the lesson relevant to the child and his/her environment

- $\quad$ Its suits the learner's local background

- $\quad$ Promotes creative on the part of the teachers and students

- It helps the students to acquire and develop manual skills

- $\quad$ It stimulates the students' interest in science

- It reduces verbalization and provokes interest on the students.

The use of improvised instructional materials for science teaching cannot be overemphasized. It makes teaching/learning process lively and brings our abstract concepts into concrete reality. It should however be noted that improvisation requires creativity, curiosity and perseverance on the part of the teacher (Esu, 2004). In spite of the importance of instructional materials in the teaching/learning process and the need for improvisation where the standard ones are not available, physics teachers are still not improvising instructional materials for physics teaching. They continue to dominate the classroom with lecture teaching method. Related studies had been conducted elsewhere but none to the knowledge of the researcher had been conducted in Cross River State. This paper thus seeks to find out the perceived problems encountered by serving physics teachers in Cross River State, Nigeria that do not allow them improvise.

\section{Purpose of the Study}

This study intends to:

i) Identity the problems encountered by physics teachers in Cross River State that do not allow them improvise instructional materials for physics teaching.

ii) Find out if these problems are gender bias.

\section{Research Questions}

1) What are the problems perceived by servicing physics teachers in the process of improvising instructional materials?

2) What is the effect of gender of the teacher on the problems encountered in the process of improvisation?

\section{Research Hypothesis}

HO1: There is no significant difference in the mean response of male and female physics teachers on the perceived problems of improvisation of instructional materials.

\section{Research Method}

The study adopted the descriptive survey research design. The study was carried out in Cross River State, Nigeria. Cross River State is one of the six states in the south-south geopolitical zone of Nigeria.

The sample for the study consisted of one hundred and sixty (160) physics teachers randomly selected from the two hundred and forty three (243) government owned secondary schools in the state. This was made up of one hundred (100) males and sixty (60) females. The instrument for data collection was tagged Physics Teachers Perceived Problems of Improvisation Questionnaire (PTPPIQ). The questionnaire has two sections, Section A and section B. Section A was designed to sought information on the teachers' personal data such as local government area of school location, sex, educational qualifications while section B was a 16-item questionnaire that sought information on problems of improvisation as perceived by the serving teachers. The questionnaire was framed and weighted on a four point Likert Scale of Strongly agree (4), Agree (3), Disagree (2) and Strongly disagree (1). An item with a mean score of 2.5 and above was considered as a constraint to improvisation while an item with a mean score of below 2.5 was considered as no constraint. The choice of 2.5 is because it is the average of $4,3,2$, and 1 .

The instrument was face-validated by three experts, two in physics education and one in measurement and evaluation all from the Cross River University of Technology, Calabar. The instrument was then trial tested using thirty (30) physics teachers in schools not used for the study. The results of this trail-test was analyzed using Cronbach Alpha and reliability index of 0.81 showed that the instrument was reliable enough to be used for the study.

\section{Results}

The results of the study is as presented below:

\subsection{Answering of Research Questions}

\section{Research Question I}

What are the problems perceived by serving physics teachers in the process of improvising instructional 
materials?

Table 1: Mean and standard Deviation Results on Teachers Perceived Problems of Improvisation of Instructional Materials

\begin{tabular}{|l|l|l|l|}
\hline S/N & Items & $\bar{x}$ & SD \\
\hline 1. & Inability to identify local materials needed for improvisation & 2.75 & 0.90 \\
\hline 2. & Teachers not resourceful or skillful on the art of improvisation & 3.25 & 1.00 \\
\hline 3. & Lack of tools needed for improvisation & 3.00 & 1.10 \\
\hline 4. & No finance for procurement of materials needed for improvisation & 3.75 & 0.70 \\
\hline 5. & Stakeholders in education unwilling to cooperate with teachers & 3.50 & 0.75 \\
\hline 6. & High cost of materials needed for improvisation & 3.15 & 1.00 \\
\hline 7. & Due to large classes it is impossible to improvise & 3.50 & 0.80 \\
\hline 8. & Excess workload & 2.65 & 1.11 \\
\hline 9. & Physics syllabus is voluminous & 3.15 & 0.85 \\
\hline 10. & Improvisation is time consuming & 3.50 & 0.95 \\
\hline 11. & Poor science teachers' motivation & 3.65 & 1.00 \\
\hline 12. & Lack of interest in the teaching profession & 3.00 & 0.85 \\
\hline 13. & Physics teachers ill-trained & 2.75 & 0.95 \\
\hline 14. & Physics teachers afraid of the risk of improvisation & 2.00 & 1.10 \\
\hline 15. & Lack of local craftsmen e.g carpenters & 2.15 & 0.90 \\
\hline 16. & Lack of interest in the act of improvisation & 2.45 & 0.85 \\
\hline & Grand Mean/Std. Deviation & $\mathbf{3 . 0 1}$ & $\mathbf{0 . 9 3}$ \\
\hline
\end{tabular}

From table I above it could be observed that item 13, 14 and 15 were rejected. All other items were accepted as perceived problems confronting teachers in their bid to improvise physics instructional materials. Also the grand mean of 3.01 showed that on the whole teachers are faced with problems which do not allow them improvise physics instructional materials.

\section{Research Question 2:}

What is the effect of gender of teachers on problems encountered by teachers in the process of improvisation?

Table 2: Mean and Standard Deviation Results of Responses of Male and Female Teachers on Problems of Improvisation

\begin{tabular}{|l|l|l|l|}
\hline Gender & $\mathbf{N}$ & $\overline{\boldsymbol{x}}$ & S.D \\
\hline Male & 100 & 48.34 & 6.62 \\
\hline Female & 60 & 47.48 & 6.86 \\
\hline
\end{tabular}

From the results in table 2, the mean responses of the male teachers was 48.34 and standard deviation of 6.62 while that of the female teaches was 47.48 and standard deviation of 6.86 . This showed that the problems perceived by the female teachers was slightly higher than their male counterpart.

\subsection{Testing of Hypothesis}

Hypothesis I: There is no significant difference in the mean responses of male and female physics teachers on the perceived problems of improvisation of instructional materials.

Table 3: T-test Analysis of the Responses of Male and Female Physics Teachers on Problems of Improvisation

\begin{tabular}{|l|l|l|l|l|l|l|l|}
\hline Gender & $\mathbf{N}$ & $\overline{\boldsymbol{x}}$ & S.D & Df & t-cal & t-crit & Decision \\
\hline Male & 100 & 48.34 & 6.62 & 158 & 1.16 & 1.96 & Not Sig. \\
\hline Female & 60 & 47.48 & 6.86 & & & & \\
\hline
\end{tabular}

*Not significant at 0.05 alpha level.

The results in table 3 showed no significant difference on the perceived problems of improvisation between male and female physics teachers. This is because the calculated t-value (1.16) is less than the critical value (1.96). Hence the null hypothesis is retained at 0.05 level of significance.

\subsection{Discussion of Results}

The results of the study as shown in table I revealed that the teacher lack the ability to identify local materials needed for improvisation. The teachers are also not skillful or resourceful on the art of improvisation. This is expected because most of the teachers are ill-trained. The study had revealed that most of the teachers teaching physics are not specialists in the subject. Because of dearth of physics teachers in our schools, graduates of biology, agricultural science and even economics are deployed to teach physics. This is what Eshiet in Udo, Okon and Obi (2014) described as teacher improvisation. Such teachers, according to Mboto and Udo (2010) lack the skills needed for improvisation.

The responses to item 3, 4 and 5 showed that the necessary tools needed for improvisation are lacking in secondary school system. At the same time there is no finance for the procurement of these tools and worse still 
the stakeholders in education are unwilling to release money for the purchase of these tools. Improvisation, as we know does not take place in the vacuum. Tools and materials are needed for improvisation. Where there is no money to purchase these items, improvisation is hampered. The teachers response as indicated in item 6 showed some of these materials are costly and as such those teachers who may be willing to improvise could not do so with their meagre salary as no stakeholder in education is willing to support them.

Results in table I also showed that teaches teach large classes. This is largely due to the dearth of physics teachers in schools. Thus they carry excess workload as revealed by item 8 . The physics curriculum, as perceived by teachers is overloaded. Thus teachers rush to cover the syllabus and are therefore left with the option of using lecture method. The response of the teachers also showed that improvisation is time consuming and thus do not want to waste time. Uka (2007) had showed that teachers accepted that improvisation is time consuming and needed to cover the syllabus before the national examinations.

Poor teacher motivation and lack of interest had also been identified as factors hindering improvisation. Motivation is very essential if stakeholders in the education sector wants to realize maximally the objectives of the curriculum. This is why Udo and Ugbe (2016) asserted that any educational policy aimed at enhancing quality education without taking into account teachers' motivation may not achieve its goals. This lack of motivation has made the teachers not to be interested in the teaching profession as a whole. The teachers however asserted that they are not afraid of the risks involved in improvisation, there are available craftsmen to assist them and they have interest towards improvisation but are hindered by those factors enumerated above.

The results of research question two as shown in table two revealed that the mean score was slightly higher on the part of the males than the female teachers. However when the difference was tested for significance as in hypothesis one, it was observed that there was no significant difference in the response of male and female teachers. This implies that male and female teachers do not differ significantly in their perception of problems of improvisation. This results is in agreement with the findings of Abdu-Raheem and Oluwagbohunmi (2015) and Achimugu and Onojah (2017) that showed no significant effect on teacher's responses on the perceived problems of improvisation of instructional materials. This implies that male and female teachers face similar constraints as far as problems of improvisation are concerned.

\section{Conclusion}

The findings of this study showed that secondary school physics teachers face problems during the process of improvisation. The findings showed that factors such as inability of the teachers to identify materials needed for improvisation, lack of tools, teachers not being skilful, large classes and poor funding of schools had been factors besetting improvisation in secondary schools in Cross River State. Other factors included poor teacher motivation, time constraint, voluminous nature of the syllabus and excess workload due to large classes among others. The results of the null hypothesis showed that these factors are not gender bias but affect both sexes equally. It has to be noted that the absence of physics instructional material (standard or improvised) had been a major obstacle towards achieving the goals of physics education at the senior secondary level. To ameliorate this ill, the paper made some recommendations below.

\section{Recommendations}

Based on the findings of this study, the following recommendations are made:

- All stakeholders in education should intensify efforts towards improvisation/acquisition of instructional materials to ease the teaching of physics and make the classroom situation lively and the learned concepts concrete.

- Science teachers should be motivated in order to do their work effectively. The suspended science teachers allowance should be resuscitated and reviewed upwards

- The training of pre-service physics teachers should emphasis improvisation to equip the pre-service physics teachers with the skills and resourcefulness needed for improvisation so as to apply them when in service.

- Funds should be made available to schools and those funds should be released to the physics teachers to purchase all the items needed for improvisation

- Enough physics teachers should be trained and posted to schools to avoid teacher improvisation.

\section{References}

Abdu-Raheem, B. O. \& Oluwagbohunmi, M. F. (2015). Pre-service teachers' problems of improvisation of instructional materials in social studies in Ekiti State University. Journal of Education and Practice. 6(4), $15-18$.

Achimugu, L. \& Onojah, P. K. (2017). Factors hindering effective production and utilization of teacher-made instructional materials in teaching senior secondary Chemistry in Federal Capital Territory, Abuja, Nigeria. International Journal of Scientific Research in Education, 10(3), $352-361$. Retrieved $20^{\text {th }}$ November, 2018 
from http://www.ijesre.com

Eniayeju, I. E. (2005). Improvisation for effective learning of physics. The Asaba Education Technical and Science Education Journal. 1(1), 92 - 97.

Esu, A. E. (2004). Professional skills for Effective Teaching. Appraisal of Basic Issues in Educational Foundation. Calabar: Rohoboth Favor Books.

Eze, U. N. and Agbomma, V. U. (2008). Relationship between Science Teachers perceived self-efficacy and Job Performance. Journal of Educational Research, 8, $162-170$.

Federal Ministry of Education (2009). Senior Secondary School Physics Curriculum, Abuja: NERDC Press.

Federal Republic of Nigeria (2013). National Policy on Education. Lagos: NERDC Press.

Folorunso, B. (2009). Selection and use of instructional materials and resources: Basic Education Teacher's Handbook of Nigerian Educational Research and Development Council, 176 - 182.

Ige, N. P. (2004). Poor Performance in Technical College of Education: Causes and Implications. Unpublished PGDE Project, Ahmadu Bello University, Zaria, Nigeria.

Mboto, F. A. and Udo, N. N. (2010). Crises in the Nigerian Science Education system: The Case of Universal Basic Education (UBE) and Primary Science Teachers Training in Cross River State. Journal of Technical, Technology and Vocational Education. 1(1), 138 - 155.

Nwosu, A. A. (2002). Gender and acquisition of science process skills among secondary school students: Implications for Science Teaching $42^{\text {nd }}$ Annual Conference Proceedings of Science Teachers Association of Nigeria, $206-209$.

Obioha, N. E. (2006). STAN physics for senior secondary schools. Nigeria: Heinemann Educational Book Publishers.

Odo, J. N. (2015). Effects of student improvised and standard instructional materials on students' academic achievement in physics. Unpublished M.Sc (Ed) Project of the Department of Science Education University of Nigeria, Nsukka.

Ogunleye, A. O. (2008). Towards effective utilization and management of resources for the effective teaching and learning of physics. Proceedings of the $41^{\text {st }}$ Annual Conference of the Science Teachers Association of Nigeria, $283-290$.

Onasauya, S. A. and Omosewo, E. O. (2011). Effect of improvised and standard instructional materials on secondary school students' academic performance in physics, Ilorin, Nigeria. Singapore Journal of Scientific Research, 1, 68 - 76.

Oyediran, I. (2010). Improvisation of science teaching resources. Proceedings of the $40^{\text {th }}$ Annual Conference of Science Teachers Association of Nigeria, 55 - 60.

Udo, N. N. and Ugbe, U. A. (2016). Motivating secondary school science teachers for Quality Assurance in the Nigerian Education System. In Mbia, S. M. and Ugbe, U. A. (Eds). Quality Assurance in Education: Nigeria's Perspective, $221-233$.

Udo, N. N; Okon, E. E. \& Obi, D. O. (2014). Remedies to the shortage of physics teachers in Cross River State for achievement of the millennium development goals. Akamkpa Journal of Education. 3(1), 168 - 174.

Uka, I. M. (2007). Teachers' perception of teachers and pupils factors affecting children's acquisition of creative thinking and skills for technology education. Journal of Science Teachers Association of Nigeria, 42(1 \& 2), $78-84$.

Ndem Nsungo Udo holds a B.Sc degree in Physics from the University of Calabar, Calabar-Nigeria, PGDE University of Uyo, Uyo, Nigeria and M.Sc (Ed) in Physics Education, Ebonyi State University, AbakalikiNigeria. Currently he is at the final stage of his doctoral programme of Ebonyi State University Abakaliki. Mr. Udo is a Principal Lecturer in the Department of Physics, Cross River State College of Education, Akamkpa. He teaches Physics and Curriculum Studies in Science Education. Mr. Udo has authored many articles as reputable journals both nationally and internationally. He is an associate member of Science Teachers Association of Nigeria (STAN) and Curriculum Organisation of Nigeria (CON). His major hobby is research and reading.

I am grateful to the International Institute for Science Technology and Education for accepting to publish this paper. I am also very grateful to the authors whose materials I have consulted to make this paper what it is. My gratitude also goes to Mr. Michael Adalikwu who has taken pains to type this paper and to all who have contributed to make this paper a success. To God be the Glory. 